\title{
Role of Off-Farm Income in Agricultural Production and its Environmental Effect in South East, Nigeria (A Case Study of Commercial Motor Cycle Business)
}

\author{
S.I. Ume ${ }^{1 *}$, C.I. Ezeano ${ }^{2}$ and R.O. Anozie ${ }^{1}$ \\ ${ }^{1}$ Department of Agricultural Extension and Management, Federal College of Agriculture Ishiagu, \\ Ivo Local Government Area of Ebonyi State, Nigeria. \\ ${ }^{2}$ Department of Agricultural Economics and Extension, Nnamdi Azikiwe University, \\ Awka, Anambra State, Nigeria. \\ *umesmilesi@gmail.com
}

\begin{abstract}
Keywords: Roles, Off-Farm Income, Agricultural Production, environmental effects, Commercial, Motor cycle, Business.
\end{abstract}

\begin{abstract}
Role of off-farm income in agricultural production and its environmental effect in Southeast, Nigeria (a case study of commercial motor cycle business) was studied. Two hundred and forty respondents (one hundred and twenty riders and one hundred and twenty motor cycle users) were selected through multi stage random sampling techniques. The objectives of the study were captured using percentage responses, multiple regression and factor analyses. Structured questionnaire was used to collect data from the respondents. The result of socio-economic characteristics of commercial motor cycle riders showed that most riders were youthful, single and experienced. Also, most of the riders used their money generated in the business in hiring labour, procurements of farm inputs, family welfare, expansion of business and procurement of equipment. As well, the menaces caused by motor cycle to the riders and the general society were accidents, traffic jam, crimes, health challenges and gang beating. More so, the determinant factors to the motor cycle riders' income generated were number of years of experience and marital status. In addition, the effects of motor cycle operations to the environment were dusty and noisy situations, soil erosion, vegetation loss and oil spillage. The avenues in alleviating the affects of motor cycle operations on the environment were use of gadgets, educational programme, ban on the use of big motor cycle, use of traffic control and cleanliness of vehicular emission. The major problems encountered by the riders were extortions by the police, emblem, high cost of fuel and high cost of spare parts. Based on the findings the following recommendations were proffered. There is need to enhance riders' access to hearing and head protective devices and goggle gadget at affordable prices. Also, experienced and novice riders should be encouraged to remain in business through among others provision of motor cycle parts at affordable prices and rehabilitation of rural roads by the government. Finally, all forms of extortions of the riders should be checkmated and the culprits brought to book.
\end{abstract}

\section{Introduction}

Rural income generating activities (RIGA) covers all the income generating activities in the rural areas and of which off-farm or secondary income generating activity is an aspects of it. Offfarm employment according to [1] is the participation of individuals in remunerative work outside the farm which could be capable of causing sustainable development and poverty reduction among the participants and their environments. Off-farm income facilitates to preclude the seasonality of primary agricultural production, ensure multi-stream of income to cater for people's welfare, consumption smoothing or risk insurance mechanism [2, 3], absorb excess labour during agricultural off-peak periods, cushion affects of poverty especially when complemented with agriculture in many rural areas $[1,4]$. Others importance are as alternate for farmers' farm income, mechanism for easy access to land, to circumvent maximally urban drift, boost rural economy through income distribution and diversification $[6,8,9]$, abridge agricultural labour seasonality, 
output and income, reduce accessibility of family labour for farm works and enhanced expenditure on farm resources $[10,11]$.

However, the contribution of shares of off- farm income to households' varies across countries. For instance, literatures show that Honduras and Costa Rica had 22\% and 59\% respectively [15]. Nigeria had 48\% [6,13], Kenya (93\%) [14], while 31\% and 68\% for Bulgaria and Armenia respectively [15]. Among the off-farm income activities engaged by the farming household, the use of motorcycle stands prominent [19,29]

The use of two-wheel motorbike is popular in many countries and these could be linked to poverty, scantiness and ineptness of the conventional modes of transportation, fare is negotiate able depending on distance, ability to provide door to door services and no defined bus stops and specific public transport routes $[17,28]$. Other justifications for use of motorbike are ease of maneuvering traffic congestions, bad roads, high fuel economy and requires no parking lots unlike cars [19]. Studies [18, 20, 24] revealed that indirect benefits of motor cycle are as source of employment and income to motorcycle mechanics and motorcycle spare parts dealers, local revenue generating sources through taxes/levies on motorcycle owner/rider as well as motorcycle registration and licensing.

In Nigeria, commercial motor cycle riders is popularly known as 'Okada,' has gained popularity since late $1980 \mathrm{~s}$. Studies show that most of the riders are unemployed youths, retires, retrenched and artisans who are majorly victims of economic meltdown [12, 14, 17]. These motorbike commercial users operate in intra-city, inter rural and cities public transport services [21]. However, in the recent time in Nigeria, there have been public outcry as relates to this transportation system's fatalities, environmental and public health concerns from the motor cycle emission, non compliance to motor traffic regulation [21], accidents, motor bike related crimes, gang beating and crime related [18], and in effect, many state governments in the country have banned the use of motorbike in the state capitals and many other big cities, hence restricting its usage in rural and semi urban areas [19].

However, literatures show that substantial number of the riders put tangible of their income generated into farm uses in order to augment their meagre income in procuring farm inputs and payments of labour in order to boost their farm productivity, which could transcend for improved family welfare [6]. However, the amount of income generated by the commercial riders depends on among others their socioeconomic characteristics such as the age of riders, riding experience, marital status, gender, educational level and membership of organization. In related study in Ghana, [3] reported that the age of the riders, riders' experience and membership of 'Okada' organization determined the income of the riders. This study tends to evaluate roles of off- farm income in agricultural production and its environmental effect with commercial motor cycle business as a case study in South East, Nigeria as no known published work by the researcher has been done in the study area. Specifically, the objectives of the study are to

1) describe the socio economic characteristics of the respondents,

(i) identify the various uses the respondents put their acquired off-farm income into,

(ii) determining the effects of 'Okada' riding on the respondents,

(iii) assess the effect of the motorcycle riders' socio economic characteristics on their income generated,

(iv) identify the affects of motor cycle operation on the environment,

(v) identify the technologies/ avenues in alleviating the affects of motor cycle operation on the environment,

(vi) identify the constraints to motorbike riders business in the study area.

\section{Materials and Methods}

The Southeast Nigeria studied. The zone lies between latitude $5^{0} 79^{\prime}$ and $7^{0} 75^{\prime} \mathrm{N}$ of Equator and longitude $6^{0} 85^{\prime}$ and $8^{0} 46^{\prime}$ East of Greenwich Meridian. It has a total land area of 10,952.400 hectare. The zone has population of $16,381.729$ people [26]. The zone is made up of five states viz: Abia, Anambra, Ebonyi, Enugu and Imo States. It lies within the rainforest and 
derived savanna region of the country and bordered in the North by Benue and Kogi States, in the West by Delta and Rivers States, in the South by Akwa Ibom State and in the East by Cross River State.

A multi-stage random sampling technique was used to select states, Local Government Areas (LGAs), towns, commercial motor cycle riders and users (customers). At the first stage 1, three out of five states were randomly selected. In the second stage, five LGAs were randomly selected from each state. This brought to a total of fifteen LGAs. In the third stage, four towns were randomly selected from each of the LGAs, totaling sixty towns. Finally, two riders and users respectively were selected from each town. This brought to a total of two hundred and forty respondents (one hundred and twenty for riders and users respectively) for detailed study. Two structured questionnaire, one each for the sampled riders and users respectively were used to elicit information on primary data concerned, while secondary data was collected through seminars, workshops, project theses and other related periodicals. The objectives i, ii, iii and $\mathrm{v}$ were analyzed using percentage responses, while objectives iv and vi were analyzed using multiple regression and factor analyses.

\section{Model Specification}

Multiple regression analysis is represented as

$$
\mathrm{Y}=\mathrm{a}+\mathrm{b}_{1} \mathrm{x}_{1}+\mathrm{b}_{2} \mathrm{x}_{2}+\mathrm{b}_{3} \mathrm{x}_{3}+\mathrm{b}_{4} \mathrm{x}_{4}+\ldots .+\mathrm{b}_{8} \mathrm{x}_{8}+\mathrm{b}_{\mathrm{n}} \mathrm{x}_{\mathrm{n}},
$$

where $Y=$ Income in Naira $(\mathrm{N}), \mathrm{X}_{1}=$ Age (years), $\mathrm{X}_{2}=$ Marital status (Dummy), $\mathrm{X}_{3}=$ Educational level (Year), $\mathrm{X}_{4}=$ Gender (Male, 1; otherwise; 0), $\mathrm{X}_{5}=$ riding experience (years), $\mathrm{X}_{6}=$ Membership of Okada organization(Member; 1 ; otherwise, 0 ), $\mathbf{e}_{\mathbf{i}}=$ error term.

Four functional forms (linear, semi-log and Cobb-Douglas) of production function were tried and explicitly represented as:

Linear function:

$$
\mathrm{Y}=\mathrm{b}_{0}+\mathrm{b}_{1} \mathrm{x}_{1}+\mathrm{b}_{2} \mathrm{x}_{2}+\mathrm{b}_{3} \mathrm{x}_{3}+\mathrm{b}_{4} \mathrm{x}_{4}+\mathrm{b}_{5} \mathrm{x}_{5}+\mathrm{e}_{\mathrm{i}} .
$$

Double log function (Cobb Douglas):

$$
\ln (y)=\ln b_{0}+b_{1} \ln x_{1}+b_{2} \ln x_{2}+b_{3} \ln x_{3}+b_{4} \ln x_{4}+b_{5} \ln x_{5}+e_{i} .
$$

Semi Double log function:

$$
\mathrm{Y}=\ln \mathrm{b}_{0}+\mathrm{b}_{1} \ln \mathrm{x}_{1}+\mathrm{b}_{2} \ln \mathrm{x}_{2}+\mathrm{b}_{3} \ln \mathrm{x}_{3}+\mathrm{b}_{4} \ln \mathrm{x}_{4}+\mathrm{b}_{5} \ln \mathrm{x}_{5}+\mathrm{e}_{\mathrm{i}} .
$$

Exponential function:

$$
\ln Y=b_{0}+b_{1} x_{1}+b_{2} x_{2}+b_{3} x_{3}+b_{4} x_{4}+b_{5} x_{5}+e_{i} .
$$

The choice of the best functional form was based on the magnitude of the $\mathrm{R}^{2}$ value, the level of significance, and size and signs of the regression coefficients as they conform to aprioi expectation

Factor analysis was employed to identify the constraints countered by 'Okada' riders in doing their business, principal component factor analysis with varimax - rotation and factor loading of 0.3 was used. The constraints observed by riders were grouped into three factors using varimax rotation and factor loading of 0.30 . The principal component factor analysis model is stated thus

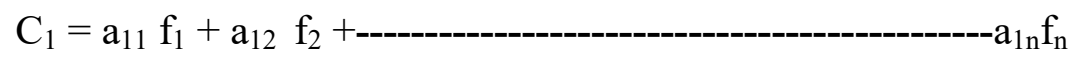

$$
\begin{aligned}
& C_{2}=a_{21} f_{2}+a_{22} f_{2}+\ldots
\end{aligned}
$$

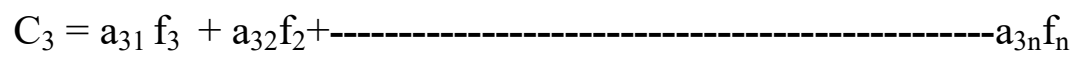

$$
\begin{aligned}
& C_{n}=a_{n 1} f_{1}+a_{n 2} f_{2}+\text {------------------------------------ } a_{n n} f_{n} \text {, }
\end{aligned}
$$


where $\mathrm{C}_{1}=\mathrm{C}_{\mathrm{n}}=$ observed variable /constraints in 'Okada' riders pdts, $\mathrm{a}_{1}=\mathrm{a}_{\mathrm{n}}=$ factor loading or correlating coefficients, $f_{1}=f_{n}=$ unobserved underlying challenging factors facing 'Okada' riders.

\section{Results and Discussion}

Table1 shows distribution of respondents according to commercial motor cycle riders' socio economics characteristics. Most of the respondents (66.7\%) were less than 31 years of age. This age group is very energetic and youthful to sustain stress associated with motorcycle business. The least $(8.3 \%)$ were of age range of $46-60$ years.

Table 1. Distribution of respondents according to socio-economic characteristics.

\begin{tabular}{|l|c|c|}
\hline \multicolumn{1}{|c|}{ Variable } & Frequency & Percentage \\
\hline Age & & 1.7 \\
\hline Less than 15 & 2 & 65 \\
\hline $16-30$ & 78 & 25 \\
\hline $31-45$ & 10 & 8.3 \\
\hline $40-60$ & & 20.8 \\
\hline Marital Status & 25 & 75 \\
\hline Married & 90 & 4.2 \\
\hline Single & 5 & 75 \\
\hline Widower & & 20.8 \\
\hline Riding Experience & 90 & 4.2 \\
\hline $1-6$ & 25 & 100 \\
\hline $7-13$ & 5 & - \\
\hline $14-19$ & & 16.7 \\
\hline Gender & 120 & 33.3 \\
\hline Males & - & 41.7 \\
\hline Females & & 8.3 \\
\hline Educational Level & 20 & 1.7 \\
\hline Non formal & 40 & \\
\hline Primary education & 50 & \\
\hline Secondary education & 10 & \\
\hline Tertiary & 2 & \\
\hline Membershipof Organization & & \\
\hline Yes & & \\
\hline No & & \\
\hline
\end{tabular}

Source, Field Survey; 2016

Furthermore, $20.8 \%$ of the respondents were married, while $75 \%$ were single. The domination of youths in the business could be attested to the fact that motor cycle is a very risky venture and could be best contained by youths and most often single ones [22]. In addition, motor cycle business was males' affairs as all the respondents (100\%) were males. Males dominate d the offfarm business because of its tedious nature which can only be contained by this gender class than the opposite one. Additionally, most $(90 \%)$ of the respondents had years of experience in motorcycle business of 1-6 years. The low number of years of Okada riding experience could be because of risks involved in the business and in effect, people engage into it as saving device for less risky and lucrative business [29].

Also, $80 \%$ of the respondents were educated, while $20 \%$ had no formal education. This is against a priori knowledge that only uneducated people is involved in 'Okada' business. However, the high number of people found in 'Okada' business could be attested to the rate of unemployment and poverty that are ravaging this country. Moreover, majority of the respondents $(98.3 \%)$ were 
members of "Okada" organization, while only $2 \%$ were not. The organization helps to protect the member against unnecessary police harassment and even the general public, train her members on safety precautions and welfare matters $[22,29]$.

Table 2 shows the various uses of acquired off-farm income as put into by the respondents

Table 2. Various uses the respondents put their acquired off-farm income into.

\begin{tabular}{|l|c|c|}
\hline \multicolumn{1}{|c|}{ Variable } & Frequency & Percentage \\
\hline Hiring Labour & 100 & 83.3 \\
\hline Procurement of Farm Inputs & 98 & 81.7 \\
\hline Family Welfare & 92 & 76.7 \\
\hline Expansion and introduction of news farm Enterprise & 80 & 66.7 \\
\hline Procurement of Farm Equipment & 75 & 62.5 \\
\hline Payment of Debt & 35 & 29.1 \\
\hline Leisure & 12 & 10 \\
\hline
\end{tabular}

Source; Field Survey; 2016.

Table 2 reveals that $83.3 \%$ of the respondents reported that they used the money generated from motorcycle business to hire labour especially during the peak of their farming seasons when cost of hiring labour is very exorbitant and the job concerned may not be easily accomplished by family labour [8]). Furthermore, $81.7 \%$ of the respondent relied on such money to buy farm inputs especially the improved types that are usually expensive and scarce during farming period. This finding concurred with [24]. Also, 76.7\% of the respondents revealed that they utilized such money to take care of their family welfare. Such welfare include smoothening family consumption, payment of children school fees and house rent, hence allowing the farm income being ploughed back into farming for higher productivity to ensue [17]. Moreover, 66.7\% of the respondents opined that such money from 'Okada' business acts as saving device to argument the farm income in order to engage in purchasing costly farm equipment. Finally, $62.5 \%$ of the sampled riders disclosed that such money could facilitate the expansion or introduction of farm business, since the savings from farm income may not be enough to embark into meaningful venture [14].

Table 3. Identify some of the menaces of 'Okada' to the Riders and the Society.

\begin{tabular}{|l|c|c|}
\hline \multicolumn{1}{|c|}{ Variable } & Frequency & Percentage \\
\hline Health Challenges & 72 & 68.4 \\
\hline Accidents & 88 & 73.5 \\
\hline Untimely death & 58 & 48.3 \\
\hline Deformation & 40 & 33.3 \\
\hline Traffic congestion & 62 & 51.7 \\
\hline Crimes & 70 & 58.3 \\
\hline Gang beating & 68 & 56.7 \\
\hline
\end{tabular}

*Multiple Responses

Source; Field Survey, 2016.

Table 3 revealed that $73 \%$ of the total respondents were of the view that motorcycle riders were responsible for many road accidents in the study. Several documentations of motor cycle related accidents are enormous to recount $[19,25,27]$. The number of motor cycle related accidents are ever on the increase and these could be associated with the non use of personal protective equipment (PPE) by 'Okada' riders, unlicensed and untrained riders, driving under the influence of drug, driving without light at night, over loading with loads by riders, carrying more than two passengers in transit, over speeding, using motor cycles with worn out tyres and poor state of Nigerian rural roads in particular $[17,25]$. Moreover, $68.4 \%$ of the respondents companied about one illnesses or the other. Severally reported health related problems of the riders are high rates of 
cases of pneumonia, finger numbness, finger stiffness, shoulder pain shoulder stiffness, prostate and testicular cancers, impotence and urinary problems [19, 20, 26, 27]. In the other way, riding is a therapy to strengthen the neck, stronger thigh and kneels and calorie burning as reported by [28]. Additionally, $58.3 \%$ of the respondents reported about motor cycle related crimes in many places where 'Okada' is operated. 'Okada' related crimes (theft of purses, mobile phones, abduction, robbery and murder) according to [25] are on the increase in city centres, urban slums and rural areas with influx of this mode of transportation. More so, $56.7 \%$ of the sampled people encountered the problem of gang beating. This barbaric attitude is often melted against other road users on any trivial provocation such as road accidents involving their members and other road users, thereby taking laws into their hands. Such attitude often escalates into serious riots which could lead to loss of properties and lives, if not properly checked by law enforcement agencies [17]. Furthermore, traffic congestion (56.7\%) was reported by the respondents. Motorcycle riders aggravate traffic congestion in the cities as the many riders are not interested in queuing up in traffic jams, rather they continue to meander from one lane to another looking for ways to beat the traffic jam $[26,28]$.

Table 4 shows the effect of motor cycle riders' socioeconomic characteristics on their income generated.

Table 4. Effect of the commercial motor cycle riders' socioeconomic characteristics on their income generated.

\begin{tabular}{|c|c|c|c|c|}
\hline Variable & Linear & Exponential & Double Log & Semi- Log \\
\hline Constant & $\begin{array}{l}31.708 \\
(4.156) * * *\end{array}$ & $\begin{array}{l}3.452 \\
(10.126) * * *\end{array}$ & $\begin{array}{l}6.810 \\
(3.682)^{* * *}\end{array}$ & $\begin{array}{l}22.844 \\
(11.355)^{* * *}\end{array}$ \\
\hline Gender & $\begin{array}{l}1.393 \\
(-2.267)^{* *}\end{array}$ & $\begin{array}{l}0.052 \\
(0.223)\end{array}$ & $\begin{array}{l}0.027 \\
(0.067)\end{array}$ & $\begin{array}{l}0.116 \\
(0.013)\end{array}$ \\
\hline Age & $\begin{array}{l}0.036 \\
(-1.143)^{*}\end{array}$ & $\begin{array}{l}0.004 \\
(-0.893)\end{array}$ & $\begin{array}{l}0.137 \\
(0.621)\end{array}$ & $\begin{array}{l}1.195 \\
(1.245)^{*}\end{array}$ \\
\hline Education & $\begin{array}{l}0.189 \\
(-8.571)^{* *}\end{array}$ & $\begin{array}{l}0.008 \\
(2.667) * *\end{array}$ & $\begin{array}{l}0.144 \\
(0.361)\end{array}$ & $\begin{array}{l}2.814 \\
(0.083)\end{array}$ \\
\hline Marital Status & $\begin{array}{l}0.064 \\
(2.127)^{* *}\end{array}$ & $\begin{array}{l}0.159 \\
(-3.720)^{* * *}\end{array}$ & $\begin{array}{l}0.252 \\
(-2.144)^{* *}\end{array}$ & $\begin{array}{l}4.347 \\
(3.083)^{* * *}\end{array}$ \\
\hline $\begin{array}{l}\text { Membership } \\
\text { Organization }\end{array}$ & $\begin{array}{l}0.076 \\
(0,087)\end{array}$ & $\begin{array}{l}0.001 \\
(0.013)\end{array}$ & $\begin{array}{l}0.036 \\
(0.421)\end{array}$ & $\begin{array}{l}0.704 \\
(0.386)\end{array}$ \\
\hline Experience & $\begin{array}{l}0.317 \\
(3.843) * * *\end{array}$ & $\begin{array}{l}0.010 \\
(-0.703)\end{array}$ & $\begin{array}{l}0.367 \\
(-3.598)^{* * *}\end{array}$ & $\begin{array}{l}1.223 \\
(0.542)\end{array}$ \\
\hline R-Square & 0.627 & 0.572 & 0.578 & 0.535 \\
\hline F-Value & $4.635 * * *$ & 3.210 & $2.190 * *$ & $2.862 * *$ \\
\hline
\end{tabular}

Source; Field Survey; 2016

Among the multiple regression analysis models used in Table 4, linear regression was chosen as lead equation. The $\mathrm{R}_{2}$ was 0.627 which implies that $62.7 \%$ of variations in the income generated by "okada "rider were accounted by the variable inputs included in the model, while the remaining $37.3 \%$ were due to error term. The coefficient of age of the rider was negative and significant at $10 \%$ alpha level. The negative coefficient of age of rider could be attested to the fact that strength and endurance needed in "Okada" business decline with age, hence negatively affecting the riders" income generated. Nevertheless, the coefficient of gender had indirect relationship with the dependent variable at $95 \%$ confidence level. The sign identity could imply that only males were involved in 'Okada'. The finding of [21] did not concur to this assertion. They opined that in Southern Nigeria, women are venturing into the business to provide specialized services with customized motorcycle. Also, the coefficient of marital status of the riders was positive and significant at 5\% risk level. Married people often have many house members and the need to meet their daily challenges of upkeep must be sustained, while the remaining are put into the farming operation .As result, they (riders) have more likelihood of spending more time in the "Okada" 
business for high income to ensue [21]. The coefficient of level of education was negative and significant at 5\% alpha level. The finding of [27] harmonized with the result. They were of the view that educated people may not have flair for motorcycle business which is usually regarded as business for illiterate but could prefer white collar job that is less stressful. More so, the numbers of years of riding experience had positive relationship to the income generated by the riders and significant at $1 \%$ probability level. The number of years of riding experience helps one to set realistic target and as well enhance one's ability to overcome intricacies involved in the business for higher income to amass [6].

Table 5 showed the effects of motor cycle operation on the environment

Table 5. Effects of commercial motor cycle operation on the environment.

\begin{tabular}{|l|c|c|}
\hline \multicolumn{1}{|c|}{ Environmental effect } & Frequency & Percentage \\
\hline Dust & 180 & 75 \\
\hline Noise & 208 & 86.7 \\
\hline Soil erosion & 156 & 65 \\
\hline Vegetation Loss & 196 & 81.7 \\
\hline Water pollution through oil spillage & 188 & 78.3 \\
\hline Introduction of non - native plant & 178 & 74.2 \\
\hline Wild life disturbances & 186 & 77.5 \\
\hline
\end{tabular}

Source; Field Survey; 2017

*multiple Responses

Table 5 showed that $86.7 \%$ of the respondents complained about noise from motor cycle. Studies revealed that high levels of noise can contribute to noise - induced hearing loss, cardiovascular effects in humans and an increased frequency of coronary artery disease [30]. In animals, noise can escalate the risk of death by altering predator or prey detection and avoidance; inhibit reproduction and navigation [31].

Also, the spill oil from motor cycle as reported by $78.3 \%$ of the respondents is capable of causing water pollution. This could result when motor cycle passes through streams or wet land or motor cycle being washed in the stream (a common practice in the study area), the engine could spills oil there, thus resulting in maiming the wild life habitation, destroy fragile water ecosystem, killing or contaminating many fish, sea bird or small organisms that are important links to the global food chain [39]. Nevertheless, the severity of the environmental harm hinges on volume of oil spilled the type and weight of the oil, place of the spill, species of the wild life in that area, timing of breeding cycle and seasonal migration [33].

Furthermore, $74.2 \%$ of the sampled population reported that motor cycle could be avenue of seed dispersal from one area to another. The introduction of non-native plants according to [34] is accomplished when motor cycle carry seeds and plant matters from other areas into the existing environment.

More so, $77.5 \%$ of the respondents opined that motor cycle noise and presence of many riders are capable of affecting wild life negatively. Studies showed that the effect of noise on wild animal life is decrease in usable habitation, which in the situation of endangered species may lead to total annihilation [31, 35, 39]. In addition, $65 \%$ of the sampled population reported that constant and large number of motor cycle operations in a given area is capable of causing soil erosion. Soil erosion is caused by the big tires churning up the earth [36].

Besides, $75 \%$ of the respondents complained that motor cycle generates lots of dusts, especially when applying on un-tarred roads. Dusts is a particulate (ultra - fine particles) that is capable of causing heart disease, lung cancer, asthma and cardiac conditions [33]. In addition, $81.7 \%$ of the respondents was of the opinion that motor cycle operation causes vegetation loss 
through emmission of sulfur dioxide from its exhaust causing crop and material damage when acidic liquid and solid aerosols are dropped on them [38].

Table 6 shows technologies for alleviating effects of motor cycle operations on the environment in the study area.

Table 6. Distribution of respondents according to technologies and avenues of alleviating effects of motor cycle operation on the environment.

\begin{tabular}{|l|c|c|}
\hline \multicolumn{1}{|c|}{ Activities } & Frequency & Percentages \\
\hline Use of gadgets & 178 & 72.2 \\
\hline Educational Programme & 190 & 79.2 \\
\hline Ban the use of big motor cycle / bikes & 180 & 75 \\
\hline Use of Traffic Control & 175 & 72.9 \\
\hline Maintenance of motor cycle & 210 & 87.5 \\
\hline Cleanliness of vehicular emission & 200 & 83.3 \\
\hline Rules and Regulation & 180 & 75 \\
\hline
\end{tabular}

Source, Field Survey, 2017 *Multiple Responses.

The above Table revealed that $87 \%$ of the respondents used maintenance of the motor cycle through inspecting equipment and vehicles regularly for immediate repairing of oil leaking parts in order to abate its pollution of streams or rivers through runoff [34].

As well, $83.3 \%$ of the respondents reported on the need for cleanlier vehicular emission as among remedies in reduction of the effects of motor motorcycle to the environment. For instance, [37] reported that motorcycle operation with bad fuel could produces lots of carbon monoxide, a greenhouse gas which is capable of damaging the central nervous system, reproduction and prenatal development, and the respiratory system [38]. Studies showed that motor cycle can releases ten times as much carbon monoxide as other gasoline-powered vehicles, and more than 80 times as much as one of the gas-electric hybrids on a per-kilometer basis [34].However, where a good fuel is used, the emission of such gases could be reduced to the barest minimum.

Furthermore, $72.2 \%$ of the sampled motor cyclist used gadgets such as mouth and nose mask while riding. This type of protection device is desirable among riders since it is capable of covering the nose, ear, and mouth together from dusts, noise and strong wind while riding [32]. In the absence of the protective devices, problems of respiratory disease asthma and other health related challenges could ensue [24]. In addition, cleanliness of vehicular emission was reported by $83.3 \%$ of the respondents as avenue in forestalling environmental degradation. The use of environmentally benign fuel sources is liable for low emission of gases such as carbon monoxide, carbon dioxide and methane which has potentials of causing pollution to the environs [36]. Studies showed that motor cycle releases ten times as much carbon monoxide as other gasoline-powered vehicles, and more than 80 times as much as one of the gas-electric hybrids on a per-kilometer basis [34]. This finding concur with [39], who reported that most cyclist purchase fuel that is considered "dirty" due to its cheaper price and this aggravate pollution of the environment with smokes of incomplete combustion of hydrocarbon. In the same vein, through the use of catalytic converters and improvements in engine design of modern motor cycle have helped in increasing efficiency in energy use at a very low noise and low emission [40]. Nevertheless, carbon monoxide, a greenhouse gas for instance is capable of damaging the human central nervous system, reproduction and prenatal development, and the respiratory system [38].

Also, the use of traffic control was reported by $72.9 \%$ of the respondents that could aid in controlling air pollution. The traffic controls will facilitate smooth vehicle flow to reduce braking and acceleration which are predisposing factor to noise pollution. In most states of Nigeria, this gadget is most fitted only in the state capitals, while other big cities where vehicular traffic jam, motor cycle inclusive is the order of the day are left out [41]. Moreover, use of educational 
programme was reported by $79.2 \%$ of the respondents as avenue of cushioning motor cycle effects on the environment through sensitizing riders conscious to riding safety and environmental management. The programme is usually organized by government agencies and non-governmental organization in form of seminar and workshop [27]. This idea is alluring but always met by poor attendance by the cyclists. Nevertheless, in the rural areas such programme is sparingly organized [17].

Besides, the use of rules and regulations in check mating environmental degradation was reported by $75 \%$ of the respondents. The government of Nigeria has rules and regulations against use of loudspeakers and other noise pollutants but enforcement is exceedingly lax especially in the rural areas [19].Besides, ban of big motor cycle / bikes as avenue of reducing noise pollution was reported by $75 \%$ of the sampled population. In the view of [32] two stroke varieties of motor cycle is a very noisy and many countries tagged them as "off - road motorcycles".

Table 7 showed the result of Varimax-Rotated factors militating against motor cycle operation.

Table 7. Varimax-rotated factors against motor cycle operation in the study area.

\begin{tabular}{|l|c|c|c|}
\hline \multicolumn{1}{|c|}{ Variable } & FI & F2 & F3 \\
\hline Police extortion & -0.0231 & $0.577^{*}$ & 0.183 \\
\hline Emblem & -0.210 & $0.429^{*}$ & 0.172 \\
\hline Bad Road network & 0.213 & 0.145 & $0.431^{*}$ \\
\hline high cost of fuel price & $0.305^{*}$ & -0.211 & 0.287 \\
\hline Theft Problem & -0.434 & -0.431 & 0.505 \\
\hline Low patronage & 0.165 & 0.017 & 0.271 \\
\hline high cost of spare parts & $0.662^{*}$ & 0.062 & -0.164 \\
\hline Disobedient to traffic rules & 0.732 & $0.304^{*}$ & -0.138 \\
\hline
\end{tabular}

Source: computed from SAS 2016.

Table 7 revealed that three factors were extracted based on the responses of the respondents; Factor $1=$ economic/institutional factor, Factor $2=$ infrastructural factor and Factor $3=$ sociofinancial factor [42]. Only variable with factor loading of 0.30 and above at $10 \%$ overlapping variance were used in naming the factors. This is in line with the finding [43] who are of the opinion that varibles with factor loading of less than 0.30 and variables that loaded more than one factor were discarded. Variables that loaded more than one factor like low patronage and theft problem were discovered. In naming the factors [43] stated that each factor is given a denomination based on the set of variables or characteristics it is composed of. It is important to note that any factor with variable loading of 0.3 and above are the important factor to be considered as serious factor militating against motorbikes operation in the study area. The important constraints under the economic /institutional factor were high cost of spare parts (0.562), high cost of pump price (305) and police extortion (0.577). The high cost of fuel is capable of reducing drastically the level of profit accruing to the riders after a day's job. The finding of [19] concurred to the assertion. On police extortion, [22] reported that this could be because of most of the 'okada' riders do not have valid particulars of their motorcycles or contravene one traffic law or the other. In effect, they bribe police in order to escape from justice. Variables that loaded under factor 2 (infrastructural factor) include; disobedient to traffic rules (0.304) emblem (0.429) and poor road network (0.431), and emblem problem. The road network is Nigeria is generally underdeveloped and in poor condition, thus making public transport to be more complex and hazardous. For instance, poor road network could negatively affect the life span of the bikes, causes enormous incidence of accidents and motor cycle theft [26]. On disobedience of traffic rules, most Okada riders defile traffic signs and rules such as wearing of helmet carrying more than one passenger, driving at night without light and dangerous over taking and speed taking [45]. Several studies [21, 25, 23] made similar finding. 
Additionally, on problem of emblem, [22] reported that there are diverse types of emblems such as Local Government Area State and Union are enforced on 'Okada with aim of extorting money from them. Hence, the riders in attempting to dodge these extortions in many occasions, lead to serious accidents and fracas with the collectors, thus leading to traffic congestions [21, 27].

\section{Conclusion and Recommendation}

The result of the socio economic characteristics of the riders showed that youths, singles and lowly experience people dominated the respondents. Also, most of the riders used their money generated from the business in hiring labour, procurements of farm inputs, family welfare, expansion of business and procurement of equipment. The menaces of motor cycle to the riders and the general society were accidents, traffic jam, crimes, health challenges and gang beating. Furthermore, the determinants of riders' income generated were number of years of experience and marital status. The impact of motor cycle operations on the environment were dusty and noisy situation, soil erosion, vegetation loss, oil spillage and wild life disturbances. The technologies and avenues of alleviating effects of motor cycle operations on the environment were use of gadgets, educational programme, ban on the use of big motor cycle, use of traffic control, cleanliness of vehicular emission and use of rules and regulation. The major problems encountered by the riders were extortion by police, emblem, high cost of fuel, high cost of spare parts and disobedience to traffic rules.

Based on the results, the following recommendations were recommended:

- First, there is need to ensure that genuine quality motorcycle spare parts are imported into the country at affordable costs.

- Secondly, Road Safety Corps and other government safety organizations should enforce use of safety devices such as wearing of helmet, driving at nights with lights and traffic gators and use of sound tires by the riders.

- Thirdly, government through its appropriate agencies should monitor the extortion of the riders through indiscriminate sales of emblems.

- Fourthly, government should rehabilitate roads particularly rural ones to enhance ease of motorcycle operation at affordable fare to the users.

- Fifth, government should reduce fuel pump price and as well enforce fill stations both in rural and urban areas to sell at government prices.

- Sixth, to ensure smooth vehicular emission, the appropriate government agencies should ensure that quality fuel is sold in filling stations, while black markets should be abolished since adulterated fuel usually has its source from there.

- Seventh, the appropriate government agencies should enforce the use of hearing protective device, goggle and mouth and noise gadgets should be worn by the riders while in business in order to forestall possible contamination with air pollutants. This could be detriment to their health.

- Eight, police officers caught extorting the riders should be brought to book for necessary disciplinary actions.

\section{Conflict of Interest}

The author declares that there is no conflict of interest. 


\section{References}

[1] T. Reardon et al., Using evidence of household income diversification to inform study of the rural nonfarm labor market in Africa, World Development. 25(5) (2012) 735-748.

[2] J. Fernandez-Cornejo, Off-farm income, technology adoption and farm economic performance. Economic Research Report No. ERR-36, Economic Research Service, U.S Department of Agriculture, Washington, D.C.2007, 57p.

[3] M. Dinye, The significance and issues of motorcycle transport in the urban areas in northern Ghana, Scientific Journal of review. 2(10) (2013) 256-272.

[4] E.C. Eboh, H.E. Ocheocha, Determinant of rural non farm sector potential in reducing income poverty, in: Proceedings of the $36^{\text {th }}$ Annual Conference of the Agricultural Society of Nigeria, October 20-24, 2001, pp. 160-164.

[5] R. Reardo, Household Income diversification into rural nonfarm activities, in: S. Haggblade, P.B.R. Hazell, T. Reardon (Eds.), Transforming the Rural Nonfarm Economy, Johns Hopkins University Press, Baltimore, 2011, 54p.

[6] J.C. Nwaru, Determinant of farm and off farm incomes and saving of food crop farmers, Niger Agric. Journal. 4(36) (2005) 26-42.

[7] F. Lopez, Off farm income and income distribution, Environment Development Economic. 12 (2007) 251-269.

[8] G. Oseni, P. Winter, Rural nonfarm activities and agricultural crop production in Nigeria, Agricultural Economics. 40(2) (2009) 189-201.

[9] E C. Haggablade, The rural and non farm Economy; prospect, growth and poverty, Reduction World Development. 38(10) (2010) 1429-1441.

[10] J. Escobal, The determinants of non-farm income diversification in Peru, World Development. 29(3) (2001) 497-508.

[11] T. Benson, Assessing African's food and nutrition security situation 2020 African Conference Brief 1 International Food Policy Research Institute Washington DC. 2004, 61p.

[12] R.O. Anozie et al., Determination of factors influencing poverty among okra producers in ohaozara agricultural zone of Ebonyi state, Nigeria, International Journal of Applied and Technology. 2(4) (2013) 26-31.

[13] M.L. Wanyama et al., Determinants off income diversification strategies amongst rural households in maize based farming systems of Kenya, African Journal of Food Science. 4(12) (2010) 754-763.

[14] P.F. Reich et al., Land resource stresses and desertification, in: Proceedings of Second International Conference on Land Degradation and desertification, KhonKaen, Thailand: Oxford Press New Delhi, 2011.

[15] K. Gbadamosi, Emergence of motorcycle in Urban transportation in Nigeria and its implication on traffic safety, Association for European Transportation and contributors publishers Inc., 2006, 27p.

[16] O.G. Olaore, Motorcycle as means of public transportation in Lagos, 1990 to present. B.A long Essay, Department of History, Olabisi Onabanjo University, Ago Iwoye, Nigeria, 2011, $12 \mathrm{p}$.

[17] A.S. Lurinola, Informal self-employment and poverty alleviation: Empirical evidence from motorcycle taxi riders in Nigeria, International Journal of Economics and Finance. 3(2) (2011) 123-145. 
[18] E.O. Odelowo, Pattern of trauma resulting from motorcycle accidents in Nigerians: a two-year prospective study, African Journal of Medicine \& Medical Sciences. 23(2) (2014) 109-112.

[19] T.R. Miller et al., Is it safest to travel by bicycle, car, or big truck?, Journal of Crash Prevention and Injury Control. 1(1) (2009) 25-34.

[20] O.O. Olubomehin, Development and impact of motorcycles as means of commercial transportation in Nigeria, Res Humanist. Soc. Sci. 2(6) (2012) 231-239.

[21] NPC (National Population Commission): Population census of Federal Republic of Nigeria: Analytical report at the national level. National Population Commission, Abuja, 2006

[22] S. Ayodele, The menace of motorcycle as a Para-transit mode in Lagos Metropolis, Nigeria, Journal of Estate Surveying Research. (2010) 64-79.

[23] World Bank, Cities on the move: A World Bank Urban transportation Strategy review. Washington D.C, World Bank Publication, 2002, 34p.

[24] S.I. Ume et al., Effect of youth rural-urban migration on child labour use in rice production in Afikpo South Local Government area of Ebonyi State, Nigeria, Asian Research Journal of Arts Social Sciences. 4(3) (2016) 260-271.

[25] R. Cervero, A. Golub, Informal transport: A global perspective, Transport Policy. 14(6) (2007) 445-457.

[26] K.S. Oluwadiya et al., Motorcycle limb injuries in a developing country, West African Journal of Medicine. 23(1) (2004) 42-47.

[27] A.S. Solagberu et al., Motorcycle injuries in a developing country and the vulnerability of riders, passengers, and pedestrians, Injury Prevention. 12(4) (2006) 266-268.

[28] T. Ogunbiyi, Much ado about okada 'ban' in Lagos. Available: http://businessdayonline.com/2014/09/much-ado-about-okada-ban-inlagos/. Accessed on June 19 th 2014.

[29] K.T. Gbadamosi, Emergence of motorcycle in urban transportation in and its implication on traffic safety, Center for Transport Studies. Department of Geography and Regional Planning, Olabisi Onabanjo University, Ago-iwoye, Ogun State, Nigeria, 2002.

[30] B. Hoffmann et al., Residence close to high traffic a prevalence of coronary disease, European Heart Journal. 27(22) (2006) 2696-2702.

[31] S.S. Reddy et al., Agricultural Economics, Oxford and IBH Publishers Co PVT Ltd., New Delhi, 2009.

[32] P. Aakko-Saksa et al., Research on unregulated pollutants emissions of vehicles fuelled with alcohol alternative fuels - VTT's contribution to the IEA-AMF Annex 44. Research Report: VTT-R-03970-14, 2014.

[33] A. Rosen, P. Olin, Hearing loss and coronary heart disease, Archives of Otolaryngology. 82 (2013) 236-242.

[34] J.M. Field, Effect of personal and situational variables upon noise annoyance in residential areas, Journal of the Acoustical Society of America. 93(5) (1993) 2753-2763.

[35] C. Jefferson, Noise Pollution, U.S. Environmental Protection Agency. Retrieved: 09-24-2013.

[36] US EPA Control of hazardous air pollutants from mobile sources. Final rule, 40 CFR Parts 59, 80, 85 and 86. United States Environmental Protection Agency, 2007.

[37] J. Escobal, A.B. Reai, The Determinants of off-farm income diversification in Latin America, World Development. 39(3) (2014) 564-606.

[38] D. Vallero, Fundamentals of air pollution, Academic Press, Saint Louis, US, 2014. 
[39] P. Aakko, N-O. Nylund, Particle emissions at moderate and cold temperatures using different fuels, Project report PRO3/P5057/03. IEA/AMF Annex 22, 2003.

[40] U. Rosenhall, K. Pedersen, A. Svanborg, Presbycusis and noise-induced hearing loss, Ear Hear. 11(4) (2011) 257-263.

[41] Environmental Protection Agency (EPA). Options for reducing methane emission internationally. Volume 1: Technological options for reducing methane emissions. Report No. EPA/400-R-9. Nigeria Environmental Protection Agency, Abuja, Nigeria. 2012, pp. 234-246.

[42] P. Siddhuraju, Antioxidant properties of various solvent extracts of total phenolic constituents from three different agroclimatic origins of drumstick tree (Moringa oleifera Lam.) leave, J. Agric. Food Chem. 51(8) (2003) 2144-2155.

[43] A.A. Enete, T.A. Amusa, Determinants of women's contributions to farming decision among cocoa-based agro forestry households in Ekiti State, Nigeria, Field Actions Science Reports. The journal of field actions. 4 (2010).

[44] A.S. Grosvenor, Health benefits of Moringa oleifera, Asia Pacific Journal of Cancer Prevention. 15(20) (2006) 8571-8576.

[45] Wikipedia. Okada commercial motorcycle. Available: http://en.wikipedia.org/wiki/Okada_(commercial_motorcycle). Accessed: October 2014. 